\title{
Mohs micrographic surgery: a study of 83 cases ${ }^{*}$
}

\author{
Cirurgia micrográfica de Mohs: estudo de 83 casos
}

\author{
Flavianne Sobral Cardoso Chagas ${ }^{1}$
}

\author{
Bruno de Santana Silva ${ }^{2}$
}

\begin{abstract}
BACKGROUND: Mohs micrographic surgery can achieve high cure rates in the treatment of skin cancer and remove a minimum of healthy tissue.

OвJестіvEs: To characterize patients undergoing Mohs micrographic surgery and study issues related to the number of surgical stages.

Methods: A descriptive, retrospective, cross-sectional study was conducted in a micrographic surgery reference center for the period of 2004 to 2010. Data was collected from medical records of 79 patients (83 surgeries).

RESUlTS: We studied 43 women and 36 men. The mean age was $57.5 \pm 14,6$ years. Skin types II and III were the most frequent, accounting for $41 \%$ and $36.1 \%$, respectively. The most frequent tumor was the basal cell carcinoma (89.1\%), and the solid subtype was the most common (44.6\%), followed by sclerodermiform histological subtype (32\%). The most frequent location was the nasal region (44.6\%). The large majority of the operated tumors were recurrent lesions $(72.7 \%)$. Half of the tumors measured $2 \mathrm{~cm}$ or more. In $68.7 \%$ of the cases two or more surgical stages were necessary for the removal of the tumors. The observation period was 2 or more years in $75 \%$ of the tumors. There was 01 post-Mohs recurrence and 02 patients had metastases during the observation period (both with squamous cell carcinoma). Conclusions: The findings coincide with those of the literature, recurrent tumors and tumors larger than $2 \mathrm{~cm}$ needed more surgical stages for their removal, although there was no statistic difference $(p=0,12$ and 0,44 respectively).
\end{abstract}

Keywords: Carcinoma, basal cell; Carcinoma, squamous cell; Mohs surgery; Skin neoplasms

Resumo: Fundamentos: A cirurgia micrográfica de Mohs é capaz de alcançar altas taxas de cura no tratamento do câncer de pele e remover o mínimo possível de tecido saudável.

Овјетіvоs: caracterizar os pacientes submetidos à cirurgia micrográgica de Mohs e estudar aspectos relacionados ao número de fases cirúrgicas. Métodos: trata-se de estudo observacional, transversal e descritivo realizado em serviço de referência para cirurgia micrográfica no período de 2004 a 2010. Foram revisados os prontuários de 79 pacientes (83 cirurgias).

Resultados: Foram avaliados 43 mulheres e 36 homens. A média de idade foi 57,5 \pm 14,6 anos. Os fototipos II e III foram os mais frequentes, respondendo por $41 \%$ e $36,1 \%$ respectivamente. O tumor mais freqüente foi o carcinoma basocelular $(89,1 \%)$, sendo o subtipo sólido o mais frequente $(44,6 \%)$, seguido pelo esclerodermiforme (32\%). A localização mais freqüente foi a nasal (44,6\%). A grande maioria dos tumores operados eram recidivados (72,7\%). Metade dos tumores mediam $2 \mathrm{~cm}$ ou mais. Foram necessárias duas ou mais fases cirúrgicas em $68,7 \%$ dos tumores para sua remoção. O tempo de acompanhamento foi igual ou superior a 2 anos em 75\%. Houve 01 recidiva pós-Mohs e 02 pacientes apresentaram metástases durante o estudo (ambos carcinomas espinocelulares).

ConClusÕEs: Os achados coincidem com os da literatura, sendo que tumores recidivados e maiores que $2 \mathrm{~cm}$ necessitaram de mais fases cirúrgicas para sua completa remoção, apesar de não haver diferença estatística ( $p=0,12$ e 0,44 , respectivamente).

Palavras-chave: Carcinoma basocelular; Carcinoma de células escamosas; Cirurgia de Mohs; Neoplasias cutâneas

Received on 30.11.2010

Approved by the Advisory Board and accepted for publication on 13.03.2011

* Work performed at a private clinic - Aracaju (SE), Brazil.

Conflict of interest: None

Financial funding: None

Resident Physician at the Dermatology Department of the Universidade Federal de Sergipe (UFS) - Aracaju (SE), Brazil.

Master in Medicine by the Universidade de São Paulo (USP) - Teacher at the Internal Medicine Department, discipline of Dermatology, of the Universidade Federal de Sergipe (UFS) - Preceptor at the Medical Residency Program in Dermatology of the Universidade Federal de Sergipe (UFS) - Aracaju (SE), Brazil. 


\section{INTRODUCTION}

Mohs micrographic surgery (MMS) is a therapeutic option for the treatment of malignant cutaneous neoplasias. This technique offers the highest cure rates for various cutaneous neoplasias, like the basal cell carcinoma (BCC) and the squamous cell carcinoma (SCC), allowing for the removal of the neoplastic tissue with minimal removal of the surrounding healthy tissue, causing less functional and aesthetic damage. ${ }^{1-10}$

The Mohs' technique consists on the removal of successive layers of tissue involved by the neoplasia, which are mapped and examined with the use of special staining, making is possible to assess both the lateral and deep margins of the tumors under the microscope. These factors are responsible for the efficiency in locating any possible extension of the tumor until the tissue completely free of tumor is obtained, regardless of the shape, size and depth. ${ }^{11}$ The process of tissue removal and microscopic analysis, after the piece is frozen, is named the surgical stage. In order to remove the whole tumor many stages might be necessary, which prolongs the surgical time and cost. The standardized methods from the anatomic pathology laboratories for analysis of the margins obtained by conventional surgery examine, usually, less than $0,01 \%$ of the total surgical margin. ${ }^{12}$

The main indications for micrographic surgery are relapsed, aggressive tumors in anatomic areas with high rates of recurrence or in areas where it is necessary to spare healthy tissue.

In Brazil the micrographic surgery is still little used, despite having been introduced in the country more than 20 years ago. ${ }^{13}$ It is of fundamental importance that the technique is disseminated amongst the dermatologic surgeons, since, when well indicated, it can deliver excellent curative and aesthetic results in the treatment of cutaneous neoplasias. In this context, the present study chose as scopes the assessment of the clinical and histological factors of the cutaneous neoplasias operated by MMS in a private clinic in the city of Aracaju (Sergipe - Brazil) and correlates them with the number of surgical stages.

\section{MATERIAL AND METHODS}

Medical charts from all the patients who had cutaneous tumors operated by the Mohs micrographic surgical technique for the period of 2004 to 2010 in a private dermatologic clinic in the city of Aracaju were retrospectively assessed. This study is classified as observational, cross-sectional, retrospective and descriptive. The sample was characterized as convenient, thus justifying the absence of calculation for the minimum sample size.

Data was collected by means of assessment of medical charts and completion of a protocol previously developed in order to group information that characterizes the clinical, epidemiological and histological profile of the patients. The developed protocol contained a series of questions answered by the participants on the day of the surgery and filled in by the doctors. The protocol had the following variables: sex, age, color, provenance, intensity of sun exposure, use of sunscreen, histology, location and size of the tumor, previous treatments to MMS, number of surgical stages and type of reconstruction.

Additional information was obtained from the patients themselves or from the legal representative, via phone call, when it was explained that the patient was absolutely free to participate on the study and that confidentiality was guaranteed.

Patients with insufficient data and/or those who could not be located during the research period were excluded. The patients received a Free and Explained Consent Form (FECF) by mail.

For the statistical analysis the PASW (Predictive Analytics Software) version 18.0 program was used, which was also used as databank. The categorical variables were summarized as simple frequencies and percentages with the respective confidence interval of 95\% when more suitable. The numerical variables were described by average and standard deviation or medians and percentiles, when necessary. In order to test the association of the results the non-parametric chi-square test $\left(\mathrm{X}^{2}\right)$ and the Fisher test were used in the case of small samples. The level of significance considered was $5 \%$.

The study was submitted to and approved by the Ethics Committee of the Universidade Federal de Sergipe, according to the protocol number 55930000107-10.

\section{RESULTS}

Medical charts from 94 patients operated on by Mohs micrographic surgery were analyzed, and 11 were excluded because of lacking data. In this study, 83 cases of Mohs micrographic surgery from 79 patients were analyzed. In terms of sex, 43 women and 36 men were studied The average age of the patients was $57,5 \pm 14,6$ years, varying from 17 to 91 years. The age range with the highest prevalence of patients operated by the Mohs technique was that of 41 to 60 years (53\%), followed by the age range of 61 to 80 years $(30,1 \%)$, as seen on graph 1 . The great majority of the patients came from the capital city of Sergipe (Aracaju) (28 patients), followed by the state of Bahia (24 patients). Fourteen patients were from the inner state of Sergipe, eleven from the state of Alagoas and two from the state of Pernambuco. The 
Number of patients operated $x$ Age range

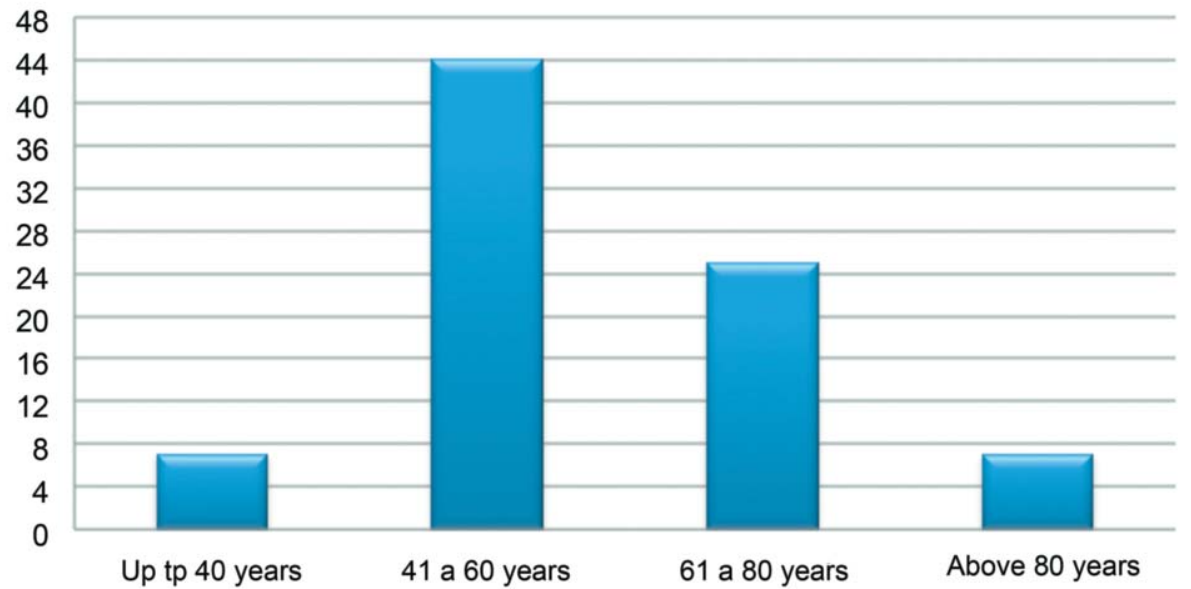

Graph 1: Prevalence of patients operated by Mohs surgery according to age range phototypes II and III were the most frequent ones, corresponding to $41 \%$ and $36,1 \%$ of the patients, respectively.

A total of 83 lesions were excised, and 74 were basal cell carcinomas $(89,1 \%)$, seven squamous cell carcinoma $(8,4 \%)$, one dermatofibrosarcoma protuberans $(1,2 \%)$ and one sebaceous gland carcinoma $(1,2 \%)$; The histological sub classification of the tumors operated by Mohs surgery is depicted on table 1 . The basal cell carcinomas were grouped into two large groups for a more objective analysis, and were classified as expansive or superficial (solid, micronodular or superficial BCC) and as sclerodermiform or infiltrating (sclerodermiform, solid or superficial with a sclerodermiform or metatypical component BCC) (Graph 2). The expansive or superficial tumors were observed in 41 patients $(49,4 \%)$ (95\% CI 38,6 to 60,2) and the sclerodermiform or infiltrating in 33 patients $(39,8 \%)(95 \%$ CI 28,9 to 49,4$)$.

Among the 83 tumors operated, 52 were recurrent $(62,7 \%, 95 \%$ CI 53,0 to 72,3$)$ and from the recurrent tumors 31 recurred more than once $(59,6 \%, 95 \%$ CI 45,9 to 72,3 ). Almost half of the recurred tumors were sclerodermiform $(46,2 \%)$ (Table 2$)$. Five tumors were operated for increasing the margin (Graph 3).

The patients with recurred neoplasias had previously undergone various types of treatments, as observed on table 3 . As for the topographic distribution, the higher prevalence on the head stands out, and the nose was the place most frequently involved $(44,6 \%)$, followed by the periocular region $(27,7 \%)$ (Table 4).

The size of the operated lesions varied from 0,4 to $12,0 \mathrm{~cm}$ on the biggest diameter (average 2,4 \pm $2,0)$, and 39 patients (50\%) had lesions equal to or bigger than $2,0 \mathrm{~cm}$ in diameter (Table 5 ).

In relation to the number of surgical stages, in most tumors $(68,7 \%)$ two or more stages were necessary for the complete removal $(31,1 \%$ one stage; $55,4 \%$ two stages and $13,3 \%$ three or more stages). Amongst the tumors which needed 3 or more surgical stages for their complete removal the rate of recurrence was $19,9 \%(n=10$, from a total of 52 patients with recurred tumors), while with the primary tumors this rate was $3,8 \%(n=1$, from a total of 26 patients with primary tumors) $(\mathrm{p}=0,12)$.

When comparing the number of surgical stages with the size of the operated tumors it was observed that amongst the tumors bigger than $2 \mathrm{~cm}$ the fre-

TABLE 1: Most common histological types of the operated tumors

\begin{tabular}{llc} 
HISTOLOGICAL TYPE & \multicolumn{2}{l}{ NUMBER } \\
& OF TUMORS \\
\cline { 2 - 3 } & 36 & $\%$ \\
SOLID BCC & 02 & 2,4 \\
MICRONODULAR BCC & 02 & 2,4 \\
SUPERFICIAL BCC & 01 & 1,2 \\
SOLID-ADENOID BCC & 22 & 26,5 \\
SCLERODERMIFORM BCC & 09 & 10,8 \\
SOLID-SCLERODERMIFORM BCC & 01 & 1,2 \\
SUPERFICIAL-SCLERODERMIFORM BCC & 01 & 1,2 \\
METATYPICAL BCC & 03 & 3,6 \\
GRADE 1/ WELL DIFERENTIATED SCC & 03 & 3,6 \\
GRADE 2/ MODERATELY & 03 & \\
DIFERENTIATED SCC & & 1,2 \\
GRADE 3/ POORLY & 01 & \\
DIFERENTIATED SCC & & \\
DERMATOFIBROSARCOMA & 01 & 1,2 \\
PROTUBERANS & & \\
SEBACEOUS GLAND CARCINOMA & 01 & 1,2 \\
\hline TOTAL TUMORS & & \multirow{2}{*}{100} \\
\hline
\end{tabular}




\section{Histology of the grouped tumors}

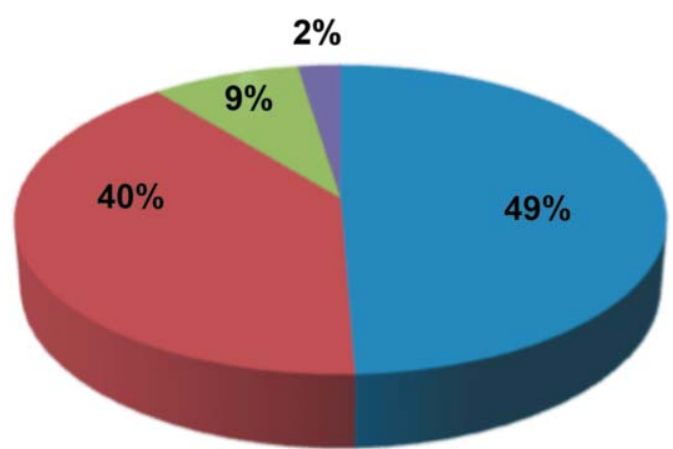

TABLE 2: Histological type of the recurred tumors before Mohs surgery

\begin{tabular}{lcc}
\hline TUMOR HISTOLOGY & \multicolumn{3}{c}{ RECURRED TUMORS } \\
& $\mathrm{N}$. & $\%$ \\
\hline $\begin{array}{l}\text { Expansive or } \\
\text { superficial BCC }\end{array}$ & 23 & 44,2 \\
$\begin{array}{l}\text { Sclerodermiform } \\
\text { or infiltrative BCC }\end{array}$ & 24 & 46,2 \\
SCC & 04 & 7,7 \\
Other tumors* & 01 & 1,9 \\
\hline TOTAL & 52 & 100 \\
\hline
\end{tabular}

quency of three or more stages was $19 \%(n=8$, total of 42 tumors $>2 \mathrm{~cm}$ ), while amongst the tumors measuring $2 \mathrm{~cm}$ or less this rate was $8,3 \%(n=3$, total of 36 tumors $\leq 2 \mathrm{~cm})(\mathrm{p}=0,44)$.

Flaps were the most used type of reconstruction $(51,8 \%)$, followed by primary closure $(32,5 \%)$, grafts $(8,4 \%)$, second intention healing $(4,8 \%)$ and flap + graft $(2,4 \%)$.

The follow up period varied from 6 to 90 months, and $75 \%$ of the patients were followed by 2 or more years, and 50\% for three or more years (Table 6). Only one patient $(1,2 \%)$ had a recurrence of the tumor after Mohs surgery, which happened after 15 months of follow up, and the histological type of the tumor was a sclerodermiform BCC. During the follow up two patients presented with metastasis from the operated tumor, and both were squamous cell carcinomas; one patient died and the other is under radiotherapy.
GRAPH 2: Operated tumors grouped by histological types

\section{DISCUSSION}

Older age and lower phototype are the known predisposing factors for cutaneous neoplasias, especially basal cell and squamous cell carcinomas, which was confirmed by this study. ${ }^{14-16}$ In this sample, $83,1 \%$ of the patients were 40 years or older, and the average age was $57,5 \pm 14,6$ years and the phototypes II and III represented $41 \%$ and $36,1 \%$ of the sample, respectively.

According to the literature the male sex is the most afflicted by skin cancer. ${ }^{17,18}$ On the present study, $54,4 \%$ of the sample was composed by women. The authors understand that this finding does not go against the literature; since the studied sample was not at random and the number of cases is inexpressive (the sample comprised only 83 cases of skin cancers specifically sent for treatment with Mohs micrographic surgery).

Most of the patients studied here came from the states of Sergipe and Bahia (42 and 24 patients). The others came from Alagoas and Pernambuco (11 and 02 patients, respectively). This data reflects the location where the work was conducted (capital city of Sergipe), bearing no relation with the prevalence of cutaneous neoplasias in Brazil. However, the fact that many patients came from other states $(46,8 \%)$ might be an indication of a need for greater dissemination of the micrographic surgery technique, as well as for the training of new specialists.

In terms of the histological type of the studied tumors, basal cell carcinomas represented $89,1 \%$ of the sample and squamous cell carcinomas $8,4 \%$. Data from the literature indicate the basal cell carcinoma as the most common type of skin cancer. ${ }^{17,18}$ Besides, infiltrative basal cell carcinomas and those located in risk areas are one of the main indications for Mohs surgery, thus justifying its high prevalence 


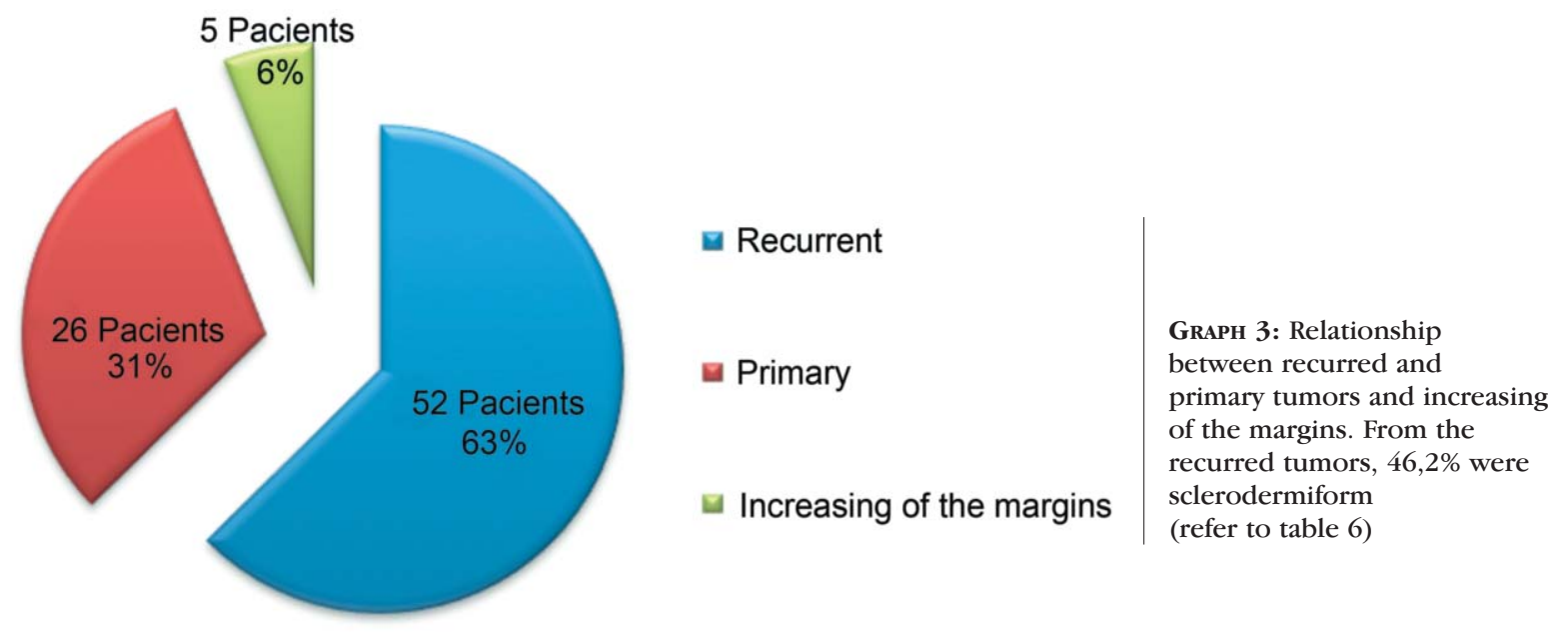

TABle 3: Previous treatments of the recurred tumors

\begin{tabular}{lcc}
\hline PREVIOUS TREATMENTS & FREQUENCY & PERCENTAGE \\
\hline Simple excision & 30 & 57,7 \\
Curettage + electrocauterization & 03 & 5,8 \\
Liquid Nitrogen & 02 & 3,8 \\
Topical (5-fluorouracil or imiquimod) & 02 & 3,8 \\
Mohs & 02 & 3,8 \\
Photodynamic therapy & 01 & 1,9 \\
Mixed & 12 & 23,1 \\
\hline
\end{tabular}

in this sample.

In the present sample recurred tumors comprised $62,7 \%$ of the cases, from which $59,6 \%$ recurred more than once. Rowe et al. showed that recurred BCC lesions, when treated by traditional methods, had a cure rate of around $82 \%$ after surgical excision and $60 \%$ after curettage and electrocoagulation. Cryotherapy (liquid nitrogen) resulted in $87 \%$ cure in series of less than five years. The use of the micrographic surgery technique in recurrent basal cell carcinomas raised the cure rates to $94,4 \%{ }^{6}$ Sclerodermiform basal cell carcinomas are the ones with the highest rates of recurrence, according to the literature. They present with infiltrating extensions in the form of cords of basaloid cells involved by a fibrous stroma, which seriously compromise their clinical delimitation. Salasche et al. found an average of $7,2 \mathrm{~mm}$ of subclinical extension in a study of 51 scle- rodermiform lesions. ${ }^{19}$ On the present study, of the 32 patients with sclerodermiform BCC operated 24 (75\%) were recurred lesions, which demonstrates the aggressiveness of these tumors.

In terms of location, it is known that the central-facial region is the area where these lesions show a more aggressive behavior, which translates into high recurrence rates. In these areas, the presence of embryonic crevices results in less resistance to the dissemination of the tumors, facilitating a higher subclinical extension of the lesions. ${ }^{20}$ Amongst the 83 tumors in the present study which were previously treated in other services and recurred, 66 (79,5\%) were located in risk areas (nose, periocular and periauricular), demonstrating their indication for micrographic surgery.

In relation to the size of the cutaneous tumors, half the patients $(50 \%)$ had lesions measuring $2 \mathrm{~cm}$ or 
TABLE 4: Topographic distribution of the operated tumors

\begin{tabular}{|c|c|c|c|c|}
\hline \multirow{2}{*}{$\begin{array}{l}\text { TUMOR LOCATION } \\
\text { NOSE }\end{array}$} & \multirow{2}{*}{$\begin{array}{c}\text { FREQUENCY } \\
37\end{array}$} & \multirow{2}{*}{$\begin{array}{l}\% \\
\text { CI } 95 \% \\
44,6\end{array}$} & \multicolumn{2}{|c|}{ CONFIDENCE INTERVAI } \\
\hline & & & 34,9 & 54,2 \\
\hline Periorbicular & 23 & 27,7 & 18,1 & 37,3 \\
\hline Periauricular & 06 & 7,2 & 2,4 & 13,3 \\
\hline Malar & 06 & 7,2 & 2,4 & 13,3 \\
\hline Trunk/ Limbs & 04 & 4,8 & 1,2 & 9,6 \\
\hline Temporal & 02 & 2,4 &, 0 & 6,0 \\
\hline Frontal & 02 & 2,4 & 0 & 6,0 \\
\hline Neck & 01 & 1,2 & 0 & 3,6 \\
\hline Nasogenian sulcus & 01 & 1,2 & 0 & 3,6 \\
\hline Perioral & 01 & 1,2 & , 0 & 3,6 \\
\hline TOTAL & 83 & 100 & & \\
\hline
\end{tabular}

TABLE 5: Size of the operated tumors

\begin{tabular}{lll}
$\begin{array}{l}\text { TUMOR DIAMETER IN ITS } \\
\text { BIGGEST AXIS (CM) }\end{array}$ & \multicolumn{2}{l}{ FREQUENCY (\%) } \\
\hline$<0,5$ & 04 & 4,8 \\
$0,5-1,0$ & 26 & 31,3 \\
$1,1-2,0$ & 14 & 16,8 \\
$2,1-3,0$ & 15 & 18,0 \\
$>3,0$ & 19 & 22,8 \\
SURGICAL SCAR & 05 & 6,0 \\
\hline TOTAL & $\mathbf{8 3}$ & $\mathbf{1 0 0}$ \\
\hline
\end{tabular}

over and $25 \%$ lesions bigger than $3 \mathrm{~cm}$. It is known that cutaneous tumors bigger than $2 \mathrm{~cm}$ have a higher risk of recurrence if they are not approached correctly, and the micrographic surgery would have a good indication in cases like this, especially in the case of tumors with infiltrative histological subtype or tumors located in risk areas, like the $\mathrm{H}$ zone of the face. ${ }^{18}$

In this study, $68,7 \%$ of the tumors needed 02 or more stages, which shows a great proportion of aggressive lesions. Besides, when comparing the size of the tumor with the number of stages there was a difference, showing that tumors measuring $2 \mathrm{~cm}$ or bigger had a higher frequency of 3 or more stages than those smaller than $2 \mathrm{~cm}$, although this difference was not significant $(19 \% \times 8,3 \%, p=0,44)$. The comparison of the number of stages with the fact that the tumors were recurrent or primary showed that recurrent ones needed more stages for their complete removal: 19,2 $\%$ needed 3 or more stages, while amongst the primary ones only $3,8 \%$ needed 3 or more stages, although there was no statistical difference $(p=0,12)$. These results indicate a tendency for these criteria to be considered as bad prognosis. The authors believe that the fact that there was no statistical significance is due to
TABLE 6: Patients' follow up period

\begin{tabular}{lll}
\hline FOLLOWUP TIME (MONTHS) & \multicolumn{2}{l}{ FREQUENCY $\%$} \\
\hline$<12$ & 19 & 22,8 \\
12 A 23 & 14 & 16,8 \\
24 A 35 & 14 & 16,8 \\
36 A 47 & 09 & 10,8 \\
48 A 59 & 09 & 10,8 \\
$\geq 0$ & 18 & 21,6 \\
\hline TOTAL & $\mathbf{8 3}$ & $\mathbf{1 0 0}$ \\
\hline
\end{tabular}

the small number of patients studied $(n=83)$. The literature shows that the highest the number of stages with micrographic surgery of a particular lesion, the highest its rate of subclinical extension. This way, the clinical criteria associated with the highest number of stages with Mohs surgery must be taken into consideration when choosing the treatment option and conventional surgery should be avoided when these criteria are present. ${ }^{13}$ The classical clinical and histological criteria for Mohs surgery are recurred tumors, those bigger than $2 \mathrm{~cm}$, location in risk areas or in areas that we must spare healthy tissue and the infiltrative histological subtype.

Data from the literature reveal that Mohs micrographic surgery has the highest cure rates in a 5 year follow up. In the present study $75 \%$ of the patients had 2 or more years of follow up, and this time varied from 6 to 90 months. During this period only one patient (total $\mathrm{n}=83$ ) had a recurrence after 15 months of follow up, which shows that the Mohs surgery is a potentially efficient surgery when well indicated and performed early. As with all surgeries, there are limitations, and there are cases of recurrence postMohs, since the cure rate is not $100 \%$ (according to 
some authors the cure rate is up to $97 \%$ in five years ${ }^{13}$ and also cases potentially aggressive which progress with metastasis, regardless of the surgical method employed.

\section{CONCLUSION}

As such, we concluded that the indication for Mohs micrographic surgery is unquestionable in cases of selected tumors with locally aggressive behavior. The indication, when present, should be early, especially in young or elderly patients with few co-morbi- dities and a good quality of life.

The present study has some limitations, like the small number of patients included in the sample (83 patients) and the follow up period shorter than the ideal in most cases $(56,4 \%$ of the patients were followed for less than 3 years). These limitations can be justified as this is a convenience type sample from a private service and employing a technique still little disseminated in Brazil.

\section{REFERENCES}

1. Motley R, Kersey P, Lawrence C; British Association of Dermatologists; British Association of Plastic Surgeons; Royal College of Radiologists, Faculty of Clinical Oncology. Multiprofessional guidelines for the management of the patient with primary cutaneous squamous cell carcinoma. Br J Dermatol. 2002;146:18-25.

2. Vuyk HD, Lohuis PJ. Mohs micrographic surgery for facial skin cancer. Clin Otolaryngol Allied Sci. 2001;26:265-73.

3. Turner RJ, Leonard N, Malcolm AJ, Lawrence CM, Dahl MG. A retrospective study of outcome of Mohs micrographic surgery for cutaneous squamous cell carcinoma using formalin fixed sections. Br J Dermatol. 2000;142:752-57.

4. Anthony ML. Surgical treatment of nonmelanoma skin cancer. AORN J. 2007;71: $550-70$.

5. Fleming ID, Amonette R, Monaghan T, Fleming MD. Principles of management of basal and squamous cell carcinoma of the skin. Cancer. 1995;75(Suppl 2):699-704

6. Rowe DE, Carrol RJ, Day CL. Prognostic factors for local recurrence, metastasis and survival rates in squamous cell carcinoma of the skin, ear and lip. Implications for treatment modality selection. J Am Acad Dermatol. 1992:26:976-90.

7. Mohs FE, Snow SN. Microscopically controlled surgical treatment for squamous cell carcinoma of the lower lip. Surg Gynecol Obstet. 1985:160:37-41.

8. Dzubow LM, Regel DS, Robins P. Risk factors for local recurrence of primary cutaneous squamous cell carcinomas. Treatment by microscopically controlled excision. Arch Dermatol. 1982:118:900-2.

9. Tramovitch TA, Stegman SJ. Microscopic-controlled excision of cutaneous tumors: chemosurgery, fresh tissue technique. Cancer. 1978;41:653-8.

10. Gross KG, Steinman HK, Rapini RP. Mohs surgery: fundamentals and techniques. St Louis: Mosby; 1999. 369 p.

11. Peçanha PL, Fraga S. Tratamento cirúrgico do câncer de pele: A cirurgia micrográfica de Mohs. An Bras Dermatol. 1991;66:181-4.

12. Cernea SS. Experiência do grupo de cirurgia micrográfica de Mohs do HCFMUSP: dezembro/1989 a abril/1993. An Bras Dermatol. 1994:69:365-73.
13. Maia M, Proença NG, Moraes JC. Risk factors for basal cell carcinoma: a case control study. Rev Saúde Pública. 1995;29: 27-37.

14. Mahmoud SF, Azadeh B. Basal cell carcinoma in Qatar. Int J Dermatol. 1996;35:704-6.

15. Castilho IG, Souza MAA, Leite RMS. Fotoexposição e fatores de risco para câncer da pele: uma avaliação de hábitos e conhecimentos entre estudantes universitários. An Bras Dermatol. 2010;85:173-8.

16. Chuang TY, Popescu A, Su WPD, Chute CG. Basal cell carcinoma: A population based incidence study. J Am Acad Dermatol. 1990;22:413-7.

17. Leffell DJ, Fitzgerald DA. Basal cell carcinoma. In: Freedberg IM, Eisen AZ, Wolff K, Austin KF, Goldsmith LA, Katz SL, editors. Fitzpatrick's Dermatology in general medicine. 5th ed. New York: McGraw-Hill; 1999. p. 857-64.

18. Salasche SJ, Amonette R. Morpheaform basal cell epitheliomas: study of subclinical extensions in a series of 51 cases. J Dermatol Surg Oncol.1981;7:387- 94.

19. Lang PG, Maize JC. Basal cell carcinoma. In: Friedman RJ, Rigel DS, Kopf AW, Harris MN. Cancer of the skin. New York: Saunders; 1991. p.5-73.

20. Kopke LFF. Cirurgia micrográfica. In: Fonseca FP, Rocha PRS. Cirurgia ambulatorial. 3. ed. Rio de Janeiro: Editora Guanabara Koogan S.A; 1999. p. 230-8.

\author{
MAILING ADDRESS: \\ Rua Ananias Azevedo, 100, apto 702, \\ Treze de Julbo, \\ 49020080 Aracaju-Sergipe. \\ tel.: 79 4141-2750/ $799122-2510$ \\ E-mail: flavianne.cardoso@globo.com
}

How to cite this article: Chagas FSC, Silva BS. Mohs micrographic surgery: a study of 83 cases. An Bras Dermatol. $2012 ; 87(2): 228-34$. 